\title{
Front Matter: Volume 10772
}

, "Front Matter: Volume 10772," Proc. SPIE 10772, Unconventional and Indirect Imaging, Image Reconstruction, and Wavefront Sensing 2018, 1077201 (14 November 2018); doi: 10.1117/12.2516573

EDIE Event: SPIE Optical Engineering + Applications, 2018, San Diego, California, SPIE. United States 


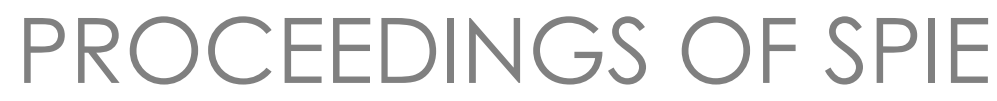

\section{Unconventional and Indirect Imaging, Image Reconstruction, and Wavefront Sensing 2018}

Jean J. Dolne

Philip J. Bones

Editors

22-23 August 2018

San Diego, California, United States

Sponsored and Published by

SPIE

Volume 10772 
The papers in this volume were part of the technical conference cited on the cover and title page. Papers were selected and subject to review by the editors and conference program committee. Some conference presentations may not be available for publication. Additional papers and presentation recordings may be available online in the SPIE Digital Library at SPIEDigitalLibrary.org.

The papers reflect the work and thoughts of the authors and are published herein as submitted. The publisher is not responsible for the validity of the information or for any outcomes resulting from reliance thereon.

Please use the following format to cite material from these proceedings:

Author(s), "Title of Paper," in Unconventional and Indirect Imaging, Image Reconstruction, and Wavefront Sensing 2018, edited by Jean J. Dolne, Philip J. Bones, Proceedings of SPIE Vol. 10772 (SPIE, Bellingham, WA, 2018) Seven-digit Article CID Number.

ISSN: 0277-786X

ISSN: 1996-756X (electronic)

ISBN: 9781510621152

ISBN: 9781510621169 (electronic)

Published by

SPIE

P.O. Box 10, Bellingham, Washington 98227-0010 USA

Telephone +1 3606763290 (Pacific Time) · Fax +1 3606471445

SPIE.org

Copyright (C) 2018, Society of Photo-Optical Instrumentation Engineers.

Copying of material in this book for internal or personal use, or for the internal or personal use of specific clients, beyond the fair use provisions granted by the U.S. Copyright Law is authorized by SPIE subject to payment of copying fees. The Transactional Reporting Service base fee for this volume is $\$ 18.00$ per article (or portion thereof), which should be paid directly to the Copyright Clearance Center (CCC), 222 Rosewood Drive, Danvers, MA 01923. Payment may also be made electronically through CCC Online at copyright.com. Other copying for republication, resale, advertising or promotion, or any form of systematic or multiple reproduction of any material in this book is prohibited except with permission in writing from the publisher. The CCC fee code is 0277$786 \mathrm{X} / 18 / \$ 18.00$.

Printed in the United States of America.

Publication of record for individual papers is online in the SPIE Digital Library.

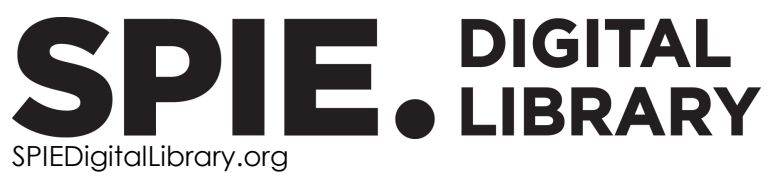

Paper Numbering: Proceedings of SPIE follow an e-First publication model. A unique citation identifier (CID) number is assigned to each article at the time of publication. Utilization of CIDs allows articles to be fully citable as soon as they are published online, and connects the same identifier to all online and print versions of the publication. SPIE uses a seven-digit CID article numbering system structured as follows:

- The first five digits correspond to the SPIE volume number.

- The last two digits indicate publication order within the volume using a Base 36 numbering system employing both numerals and letters. These two-number sets start with $00,01,02,03,04$, 05, 06, 07, 08, 09, 0A, OB ... 0Z, followed by 10-1Z, 20-2Z, etc. The CID Number appears on each page of the manuscript. 


\title{
Contents
}

\author{
vii Authors \\ ix Conference Committee
}

\section{SESSION 1 WAVE OPTICS}

1077202 Wave-optics comparisons to a scaling-law formulation [10772-1]

1077203 Light-field reconstruction from scattered light using plenoptic data [10772-2]

1077204 Progress in image formation in deep turbulence with laser illumination [10772-42]

SESSION 2 WAVE OPTICS SIMULATION FOR BEAM CONTROL: JOINT SESSION WITH CONFERENCES 10770 AND 10772

1077205 Influence functions of a deformable mirror: least-squares wave-front fitting [10772-3]

1077206 Investigation of branch-point density using traditional wave-optics techniques [10772-4]

1077207 Wave-optics simulation of correlated speckle fields for use in closed-loop-phasecompensation studies [10772-5]

1077208 Investigation of turbulence thermal blooming interaction using the split-step beam propagation method [10772-6]

\section{SESSION $3 \quad$ WAVEFRONT SENSING}

1077209 Dual wavefront sensing design for supersonic wind tunnel experiments [10772-7]

10772 OA An analytical study on the presence of inter-modal cross-talk in a modal wavefront sensor [10772-8]

$10772 \mathrm{OB} \quad$ Truncation robust centroiding for wavefront sensors [10772-9]

10772 OC Profiling of atmospheric turbulence along a path using two beacons and a Hartmann turbulence sensor [10772-10]

10772 OD Improvement in modal wavefront sensing in terms of cross-talk reduction and linearity [10772-11] 
$10772 \mathrm{OE} \quad$ Super-resolution imaging via expectation-maximization estimation of near stellar neighborhoods [10772-12]

10772 OG Performance limits and trade-offs of superresolution imaging systems [10772-14]

SESSION 5 IMAGING INSTRUMENTS

$10772 \mathrm{OH} \quad$ Distributed-volume optical disturbance generation in a scaled-laboratory environment using nematic liquid-crystal phase modulators [10772-15]

$10772 \mathrm{Ol} \quad$ Laser scanning confocal microscopy using illumination beams with different polarizations in quick succession [10772-17]

10772 OJ High-contrast imaging of space objects using diffractive optics [10772-18]

\section{SESSION 6 IMAGING FOR BIOLOGY AND UNDERSTANDING}

10772 OM Multi-domain constraint based one-step selective-reconstruction method for spectral micro-CT [10772-20]

1077200 The potential for Poisson image reconstruction models for electron tomography [10772-22]

10772 OP Molecular imaging with x-ray free-electron lasers [10772-23]

SESSION 7 ADAPTIVE OPTICS AND BEAM FORMATION

10772 OR Polychromatic speckle mitigation for improved adaptive-optics system performance [10772-26]

10772 OS On-sky results and performance of low latency centroiding algorithms for adaptive optics implemented in FPGA [10772-27]

10772 OT Optical diagnosis of laser plasma based on coherent modulation imaging [10772-28]

10772 OU Water-cooled stacked-actuator deformable mirror for high CW power laser beam correction [10772-29]

10772 OV Fast adaptive optical system for 1.5 km horizontal beam propagation [10772-30]

10772 OW Laser beam focusing through the scattering medium-low order aberration correction approach [10772-31] 
10772 0X Ghost image generated by relative movement of target and lidar platform in enhanced selfheterodyne SAIL [10772-32]

10772 OY Effect of aberration on the electric field orientation around the focus of a polarized light beam [10772-33]

$107720 Z$ 3D coherent imaging ladar based on FMCW technology [10772-34]

1077210 The accuracy reconstruction of phase map optical field using of a 2D Hilbert transform [10772-35]

1077211 The reconstruction of the phase distribution of the intensity of a speckle field based on the use of the discrete 2D "window" Hilbert transform [10772-36]

$1077216 \quad$ Online submillimeter three dimensional imaging of magnetic and paramagnetic contaminants flow rate in multiphase flow pipelines using magnetic particle imaging technique [10772-43]

1077217 Real-time ECT-based imaging device for solid contaminants imaging [10772-44] 
Proc. of SPIE Vol. 10772 1077201-6

Downloaded From: https://www.spiedigitallibrary.org/conference-proceedings-of-spie on 25 Apr 2023 Terms of Use: https://www.spiedigitallibrary.org/terms-of-use 


\section{Authors}

Numbers in the index correspond to the last two digits of the seven-digit citation identifier (CID) article numbering system used in Proceedings of SPIE. The first five digits reflect the volume number. Base 36 numbering is employed for the last two digits and indicates the order of articles within the volume. Numbers start with 00, 01, 02, 03, 04, 05, 06, 07, 08, 09, OA, OB...0Z, followed by 10-1Z, 20-2Z, etc.

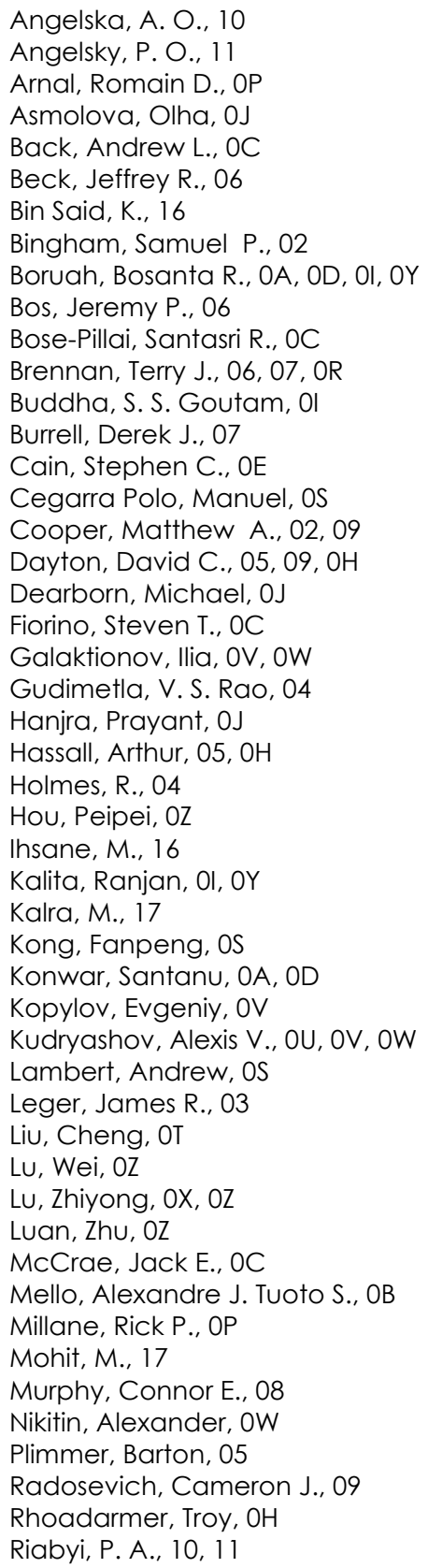

Rice, Christopher A., OC

Rodrigues Pipa, Daniel, OB

Rukosuev, Alexey, OU, OV

Samarkin, Vadim, OU, OV, OW

Sanders, Toby, 00

Sasaki, Takahiro, 03

Selph, Benjamin, 09

Sheldakova, Julia, OU, OW

Spencer, Mark F., 02, 05, 06, 07, 08, 09, OH, OR

Sun, Jianfeng, OX, $\mathrm{OZ}$

Tao, Hua, OT

Testorf, Markus E., OG

Toporovskiy, Vladimir, OU

Van Zandt, Noah R., 02, 07, OR

Vieira, Lucas Edson Lopes, OB

Wang, Qian, OM

Wilcox, Christopher C., 09

Wilson, Matthew D., OC

Wittich, Donald J., 09

Wojtas, David H., OP

Xu, Qian, $0 Z$

Young, Elizabeth J., 0

Yu, Hengyong, $\mathrm{OM}$

Zhang, Guo, OX

Zhou, Yu, OX, OZ

Zhu, Jianqiang, OT

Zhu, Yining, OM 
Proc. of SPIE Vol. 10772 1077201-8

Downloaded From: https://www.spiedigitallibrary.org/conference-proceedings-of-spie on 25 Apr 2023 Terms of Use: https://www.spiedigitallibrary.org/terms-of-use 


\title{
Conference Committee
}

\author{
Program Track Chairs
}

Stephen M. Hammel, SPAWAR Systems Center, Pacific (United States)

Alexander M. J. van Eijk, TNO Defence, Security and Safety

(Netherlands)

\section{Conference Chairs}

Jean J. Dolne, The Boeing Company (United States)

Philip J. Bones, University of Canterbury (New Zealand)

\section{Conference Program Committee}

Mark A. Anastasio, Washington University in St. Louis (United States) Stephen C. Cain, Air Force Institute of Technology (United States) Joe Chen, Arizona State University (United States) Richard Clare, University of Canterbury (New Zealand) David C. Dayton, Applied Technology Associates (United States) Peter C. Doerschuk, Cornell University (United States) Veit Elser, Cornell University (United States) James Fienup, University of Rochester (United States) Victor L. Gamiz, Air Force Research Laboratory (United States) Richard B. Holmes, Boeing LTS Inc. (United States) Kenneth J. Jerkatis, Applied Technology Associates (United States) Andrew J. Lambert, UNSW Canberra (Australia) Liren Liu, Shanghai Institute of Optics and Fine Mechanics (China) Zhaowei Liu, University of California, San Diego (United States) Julian Maclaren, Stanford University (United States) Rick P. Millane, University of Canterbury (New Zealand) Sergio R. Restaino, U.S. Naval Research Laboratory (United States) Mark F. Spencer, Air Force Research Laboratory (United States) Markus E. Testorf, Dartmouth College (United States) David G. Voelz, New Mexico State University (United States) Kevin J. Webb, Purdue University (United States) David Wojtas, University of Canterbury (New Zealand) Jong Chul Ye, KAIST (Korea, Republic of) Chun Hong Yoon, SLAC Stanford University (United States)

Session Chairs

1 Wave Optics

Philip J. Bones, University of Canterbury (New Zealand) 
2 Wave Optics Simulation for Beam Control: Joint Session with Conferences 10770 and 10772

Jeremy P. Bos, Michigan Technological University (United States) Mark F. Spencer, Air Force Research Laboratory (United States)

3 Wavefront Sensing

Richard B. Holmes, Boeing LTS Inc. (United States)

4 Deconvolution and Superresolution

David C. Dayton, Applied Technology Associates (United States)

5 Imaging Instruments

David Wojtas, University of Canterbury (New Zealand)

6 Imaging for Biology and Understanding

Markus E. Testorf, Dartmouth College (United States)

$7 \quad$ Adaptive Optics and Beam Formation

Jean J. Dolne, The Boeing Company (United States) 